\title{
Capital de giro
}

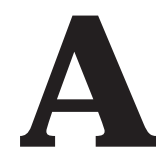

s finanças corporativas possuem três decisões fundamentais: investimentos, financiamentos e distribuição de resultados (dividendos). Estas são decisões que recebem grande atenção da empresa, de seus acionistas e da mídia especializada, pois envolvem enormes quantias monetárias, definem o futuro de longo prazo da empresa e, conseqüentemente, causam grandes impactos nos resultados da organização.

Entretanto, embora esquecido por alguns, o capital de giro é também uma das principais decisões financeiras da empresa, com a diferença de que é enfrentada diariamente pelos gestores da organização, ao contrário das três grandes outras decisões, as quais ocorrem poucas vezes no ano ou durante o ciclo operacional da empresa.

Segundo dados do SEBRAE de 2004, a principal causa para o fechamento de empresas é a falta de capital de giro. Em muitos casos, isso ocorre devido à ausência de planejamento e de uma estimativa correta do total de investimento necessário, decorrentes da falta de conhecimento sobre a dinâmica e a gestão do giro do negócio. O SEBRAE também reporta que 0 investimento em capital de giro representou um terço do investimento total realizado pelas empresas e, apesar de toda essa quantia investida, as empresas da amostra fecharam por falta de capital de giro.
Ora, se a gestão de capital de giro é importante para pequenas e médias empresas, o que dizer para as grandes corporações? Só para citar alguns exemplos, se observarmos as recentes aberturas de capital na Bolsa de Valores de São Paulo, notaremos que grandes empresas, como Gafisa e Rodobens, destinaram aproximadamente $15 \%$ da emissão de ações para investimento em capital de giro, ou respectivamente R\$ 71 milhões e R\$ 55 milhões.

Se a falta de capital de giro pode culminar com a quebra da empresa, seu excesso, porém, pode comprometer a rentabilidade do negócio, pois os ativos que o compõem geram baixos retornos, afetando, dessa forma, a criação de valor do negócio. Como conseqüência, isso torna o capital de giro um mal necessário. Se deum lado elepossui baixo retorno, por outro, é essencial para a sobrevivência da empresa.

A meta governamental esperada para o crescimento da economia brasileira elevará a necessidade de capital de giro para as empresas, fazendo com que o próprio governo e as instituições financeiras tenham que lançar novos produtos para as organizações dos mais variados portes. Além de novas fontes de recursos financeiros, especialmenteos agentes do sistema financeiro, é igualmente necessário que haja um esforço para a formação de administradores especializados em capital de giro, de modo a garantir um melhor planejamento e análise de viabilidade do negócio. 